\title{
Office Development, Rail Transit, and Commuting Choices
}

\author{
Robert Cervero, University of California, Berkeley
}

\begin{abstract}
Decentralized employment growth has cut into transit ridership across the United States. In California, about 20 percent of those working in office buildings near rail stations regularly commute by transit, nearly three times transit's modal share among those working away from rail stations. Mode choice models reveal that office workers are most likely to rail-commute if frequent feeder bus services are available, their employers help cover the cost of taking transit, and parking is in short supply. Factors like trip-chaining and the absence of restaurants and retail shops near suburban offices, however, deter transit-commuting. Policy-makers can promote transit-commuting to offices near rail stops by flexing parking standards, introducing high-quality feeder buses, and initiating workplace incentives such as deeply discounted transit passes. While housing has generally been the focus of transit-oriented development, unless the other end of the commute trip-the workplace-is also convenient to transit, transit will continue to struggle in winning over commuters in an environment of increasingly decentralized employment growth.
\end{abstract}

\section{Introduction}

Transit oriented development (TOD) - compact, mixed-use development around transit stations-has gained popularity as a smart-growth strategy. A national survey recently identified more than 100 TODs across the United States that were self-identified by local transit-agency planners (Cervero et al. 2004). TOD is arguably the most cogent form of smart growth: lay citizens and politicians alike 
can relate to the idea that if there is any logical place to target dense, mixed-use development, it is in and around transit stations.

If there is any single aspect of TOD that all sides agree is beneficial to society, it is increased ridership. According to its backers, TOD can relieve traffic congestion, improve air quality, cut down on tailpipe emissions, and increase pedestrian safety in transit-served neighborhoods by coaxing travelers out of their cars and into trains and buses.

To date, TOD's ridership benefits have focused on residential development, with studies generally concluding that residents living near U.S. rail stations are five to six times more likely to commute via transit than the typical commuter in a region (JHK and Associates 1987, 1989; Cervero 1994a; Bernick and Cervero 1997; Lund et al. 2004). The "ridership bonus" associated with TOD residences is mainly a product of self-selection (Cervero et al. 2004). Those with a lifestyle predisposition for transit-oriented living conscientiously sort themselves into housing within an easy walk of a transit node and act on these preferences by frequently taking transit. That is, being near transit and being able to get around via trains and buses weighs heavily in residential location decisions.

While the relationship between living near and riding transit is fairly well understood, less is known about the ridership impacts of working near transit. Self-selection is less likely at play since the ability to commute via transit weighs less heavily in choosing a workplace than a residence. In view of this, is there a discernable ridership bonus associated with transit-oriented working?

The relationship between transit and workplace location is partly important in light of unfolding employment trends. As employment continues to decentralize into areas with meager transit services, increasing reliance on the private automobile can be expected. Past research shows that the trend toward low-density office development partly explains modal shifts to the private car (Cervero 1989; Cervero and Landis 1992; McDonald and Prather 1994). During the 1990s, more U.S. office growth occurred in the loose constellation of multitenant office buildings strung along county and minor roads, what Lang (2003) calls "edgeless cities," than in the compact, mixed-use suburban downtowns, or "edge cities," popularized by Garreau (1991). By 2000, edgeless cities accounted for more total office space than the downtowns of 11 of America's 13 largest metropolitan areas (Lang 2003).

Part of the rationale behind TOD is to channel decentralized growth into a form that is more conductive to transit riding. Most TODs that are taking form outside 
of downtown districts, however, have been oriented toward housing construction (Dittmar and Ohland 2004). Single-use (i.e., housing-only) development around transit stations, however, is unlikely to yield significant mobility dividends. Past research shows that station-area residents are far more likely to transit-commute if their workplaces are also near transit (Cervero 1994a), particularly among those working outside of downtown districts who can park for free (JHK and Associates 1989; Cervero 1994a). That is, for suburb-to-suburb commutes, both trip origins and destinations need to be reasonably close to transit if middle-income "choice" commuters are to ride transit in significant numbers. This is very much the Scandinavian model: trains and buses are filled in both directions along transit corridors in greater Stockholm and Copenhagen in large part because both housing and job sites are concentrated in and around rail nodes (Cervero 1998).

This article examines the impacts of office development around rail stations on transit mode choice, drawing on a large survey of those working in office buildings in California's largest metropolitan areas. In addition to studying impacts of building proximity to rail stations on commute mode choice, the effects of workplace parking and policy variables are also probed. Moreover, the influences of factors like trip distance and street connectivity on midday travel choices of those working near rail stations are examined. The article concludes with discussions on the policy implications of the research findings.

\section{Past Research}

Many offices experience high rates of transit ridership by virtue of the fact that they are located downtown where levels of transit accessibility are the highest. Outside of downtowns, however, the availability of free parking combined with the sparser and less frequent levels of service sharply erodes transit ridership. In the case of the San Francisco Bay Area, for instance, 49 percent of those working in downtown San Francisco commuted by transit in 2004 compared to under 5 percent of those who worked in nondowntown areas (RIDES for Bay Area Commuters, Inc. 2004).

Evidence on the ridership impacts of rail-oriented office development comes mainly from metropolitan Washington, D.C. and California. Surveys of rail-commuting in metropolitan Washington, D.C. found that nearly 50 percent of those working in offices within 1,000 feet of downtown Metrorail stations rail-commuted. In the case of offices that were comparable distances from the more 
suburban Crystal City and Silver Spring stations, the shares were 16 percent to 19 percent (JHK and Associates 1987). Place of residence was a particularly important explainer of whether office workers patronized transit. In the case of the Silver Spring Metro Center, a 150,000-square-foot office tower 200 feet from the Metrorail portal, 52 percent of workers who lived in Washington, D.C. rail-commuted; among those living in surrounding Montgomery County, Metrorail was used by just 10 percent (JHK and Associates 1989).

Surveys of those working in offices near rail stations in the San Francisco Bay Area in the early 1990s found that around 1 of 10 individuals got to work by transit (Cervero 1994b). Suburban station-area workers were 21/2 times more likely to get to work by rail than other Bay Area commuters. As in metropolitan Washington, living near transit made a difference. On average, 19.3 percent of those who lived in a city served by Bay Area Rapid Transit (BART) trains and who worked near a BART station commuted by rail compared to 12.8 percent of those who worked in a similar setting but did not live in a BART-served city. A similar mode split-18 percent-was found among those working at a mixed office-retail air-rights building on the edge of downtown San Diego (Martin 1996). The Bay Area study found office densities around suburban stations had a positive influence on ridership. For every additional 100 employees per acre, rail ridership rose 2.2 percent, on average. Clustering of suburban workplaces around stations is important since as long as office development is geographically close and oriented to rail transit (i.e., within a convenient walking distance), experiences indicate that reasonable shares of workers will commute via transit.

\section{Modal Share Impacts of Rail-oriented Office Development}

To examine the modal split implications of office development near rail during this era of "edgeless city" growth, I codirected a study that surveyed workers at 10 predominantly suburban office buildings situated within $1 / 2$ mile of a rail station in five California metropolitan areas: Los Angeles-Orange County, Sacramento, San Diego, the East Bay (Alameda and Contra Costa Counties) and the South Bay (Santa Clara County) of the San Francisco Bay Area (see Lund et al. 2004, for details). These buildings were chosen, in part, to correspond with the seven railoriented office buildings that I surveyed and studied in 1992 (Cervero 1994b), thus providing a time-series perspective. Workers at the 10 office buildings voluntarily completed self-reported surveys on their commute trips and travel during their work hours in the spring of 2003. A total of 877 surveys were received, yielding a 
20 percent response rate. The 10 surveyed office buildings were served by three types of rail services: heavy rail in the San Francisco Bay Area (BART) and Los Angeles (Metrorail-Red Line); light rail in San Diego (Trolley), Sacramento (Regional Transit), and Santa Clara County (Valley Transit Authority); and commuter rail serving Orange County (Metrolink). Employment densities of the surveyed office buildings ranged from 8 to 37 jobs per net acre, below the benchmark of 50 jobs per acre sometimes used as a minimum threshold to justify rail transit investments (Ewing 1998).

\section{Ridership Bonus}

Based on the survey results, there was a clear ridership premium associated with working near a rail station, at least among Californians in 2003. Rail or bus was the primary commute mode for 18.8 percent of the surveyed office workers. This was nearly three times the weighted average of 6.3 percent of commutes by transit among workers of the seven California counties from which the office-building sample was drawn, based on Part II (place-of-work) data from the 2000 Census Transportation Planning Packages (CTPPs). While having nearly one out of five office workers in fairly low density settings commuting via transit is impressive by U.S. standards, this was miniscule compared to the just over two-thirds of survey respondents who solo-commuted, despite the close proximity of the sampled buildings to frequent peak-period rail services. Around 10 percent of those surveyed arrived to work in a carpool, and just over 3 percent commuted by foot or bicycle.

Interestingly, for the seven recently surveyed office buildings that were also surveyed in 1992, 23.9 percent of workers commuted by transit. This compares to a transit market share of 14.3 percent among the workers of the same buildings surveyed in 1992. A simple difference of proportions comparison reveals this marketshare increase is statistically significant at the .01 probability level. Why? It could be that a rail-served office location gained value over time as more and more Californians opted to move to housing near rail stops. Additionally, all large California metropolitan areas experienced employment growth and, correspondingly, worsening traffic congestion during the 1992-2003 period, factors that could also have had a hand in the rising share of transit-commuting among rail-oriented workers.

Aggregating the modal split data for all survey respondents within each office building allowed a simple plot of transit shares as a function of distance to station. Figure 1 shows that work-trip market shares fell with distance in a negative expo- 


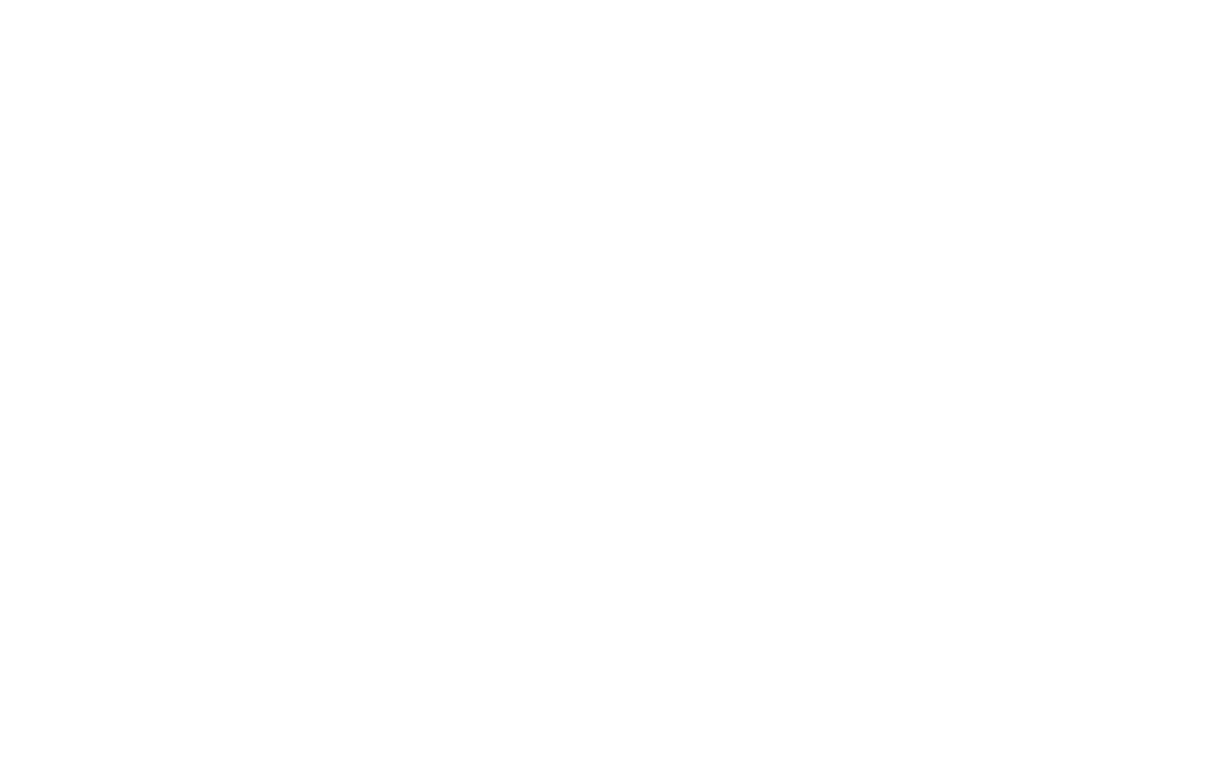

\section{Figure 1. Ridership Gradient: Transit Share as a Function of Distance of Office Site to Nearest Station}

nential fashion. The best-fitting equation, estimated from these 10 data points, took the form:

Estimated proportion of commutes by transit $=$

$$
0.523-0.067 \log _{e} \text { (distance), } R^{2}=.678
$$

Notwithstanding the small sample and aggregate nature of the data, the presence of a relatively steep nonlinear slope suggests considerable ridership benefits accrue from clustering suburban employment growth around rail stations, at least in California.

Insights can be gained by examining the two outlier cases with relatively high transit mode shares in Figure 1. Besides lying relatively close to a rail station platform, the two buildings represented by these cases-the California Department of Conservation building in Sacramento (27\% transit-commute share) and Great Western Building in Berkeley (17\% transit-commute share)-also had what other buildings did not-density, mixed-use environments, and market-rate parking prices. The employment densities of the two buildings -37.6 workers per acre for the Department of Conservation and 20.6 per acre for Great Western-are 
much higher than those of the other eight projects. Comparatively high densities translated into comparative high parking costs: both projects charge more than $\$ 100$ per month to park. Moreover, there is no parking at the nearest rail stations of either office building.

\section{Station Access and Egress}

How did the surveyed rail commuters access stations? Fifty-one percent drove alone to the rail station at the home-end of their trip. Another 6 percent carpooled. A third walked and the remaining respondents reached stations by bus (7\%) or bicycle (2\%).

Once surveyed rail users reached their destination station, 78 percent got to work by foot. Most of the remaining surveyees transferred to bus to reach their offices (even though all were less than $1 / 2$ mile from the egress station).

\section{Trip Chaining}

One factor that could have cut into the share of commute trips by transit was the need to make intermediate stops to and from work. Thirty-five percent of the surveyed workers made intermediate stops. Those commuting by private cars were far more likely to chain trips than transit commuters. The main reason for intermediate stops was to pick up or drop off children (27\% of trip chains), followed by shopping ( $21 \%)$, personal business $(21 \%)$, eating (13\%), and social-recreation (8\%). The need to chain trips underscores the importance of placing multiple uses, such as child-care centers and retail shops, in and around transit stations to enable workers to consolidate trip ends. San Diego Transit, for example, has worked with local planners to site eight child-care centers within $1 / 4$ mile of light-rail stations for this very reason.

\section{Influences of Changing Workplaces}

Of the 877 office workers surveyed, 102 had changed their workplace location within the past three years to an area served by rail. Among these individuals, 47.1 percent continued to drive alone and 7.8 percent continued to take transit as their "typical" commute mode. Thus, around 55 percent did not change their commute habits after their job site changed to a rail station area. Only 10.8 percent of those who changed workplaces switched from automobile to transit (rail or bus) commuting. Surprisingly, 8.8 percent switched from transit to automobile. This suggests that factors like plentiful parking, which exceeded one space per worker at all but 1 of the 10 sampled office buildings, likely eclipsed the proximity of transit in shaping commuting choice. 


\section{Factors Influencing Transit Mode Choice}

To explore the influences of workplace policy variables and built environment factors on commuting, a best-fitting model was estimated that predicts whether surveyed office employees took transit to work. Variables entered if theory suggests they belonged in the model (e.g., travel time) or if they were statistically significant and yielded intuitive and reasonable results. Some variables, notably those related to sociodemographic attributes of workers and urban design of workplace areas, did not enter into the best-fitting model because of high multicollinearity. In all, 10 variables related to the density, mixed-use attributes, and street design features of $1 / 2$-mile rings around each surveyed office were candidates to enter the model, but because of the limited variation in these attributes, none did.

Table 1 presents the best-fitting mode-choice model, estimated in binomial logit form. Longer travel time by automobile over the highway network increased the likelihood of an office worker commuting by transit. While not statistically signifi-

Table 1. Best-Fitting Binomial Logit Model for Predicting Transit-Commute Choice Among Surveyed Office Workers 
cant at the .05 probability level, this variable was included in the model as a measure of generalized cost. Quality of transit service also mattered. As the frequency of feeder bus service at the closest stations to surveyed office sites increased, so did the odds of workers rail-commuting. Consistent with expectations, higher car ownership levels reduced the odds of office workers transit-commuting.

Two variables most easily subject to change that entered the model pertain to employer parking and workplace policies. The probability of office workers commuting by transit fell as the supply of parking relative to workforce size increased. And employer assistance in covering the cost of transit travel, such as the provision of deeply discounted Eco-passes, significantly increased the odds of transit-commuting. It follows that flexing parking standards and providing tax or impact-fee credits to businesses near transit sites that help their employees with transit costs can promote transit-commuting.

\section{Sensitivity Test}

A sensitivity test was conducted using the logit model from Table 1 to illuminate the influences of changeable variables-notably, feeder bus service frequencies and workplace policies-on commuting choice. The sensitivity results, shown in Figure 2, are for the typical worker situation, assuming an average commute by car of 30 minutes and one car per household member 16 years of age or more. The figure shows the estimated probability of a surveyed office worker commuting by transit given changes in the three policy variables in the model: frequency of feeder bus services (the covariate on the horizontal axis); whether employers help with transit costs (shown by the solid lines); and parking supplies per worker (shown by the dashed lines). With 25 feeder buses per day, an office setting with 50 percent more parking spaces than workers, and no employer help with transit costs, the model predicts that just 8 percent of office workers near a rail station will commute by transit. At the other extreme, for a worker heading to a station with 400 daily feeder buses who works for an employer who provides transit-pass assistance and provides one parking space for every two workers, the likelihood he or she will commute by transit is 50 percent. Over the range of feeder bus frequencies, the differential in transit-commuting probabilities is 30 to 40 percent depending on how generous employers are in promoting transit (i.e., minimal parking and help with transit costs) or in accommodating the automobile (i.e., ample parking and no help with transit costs). 


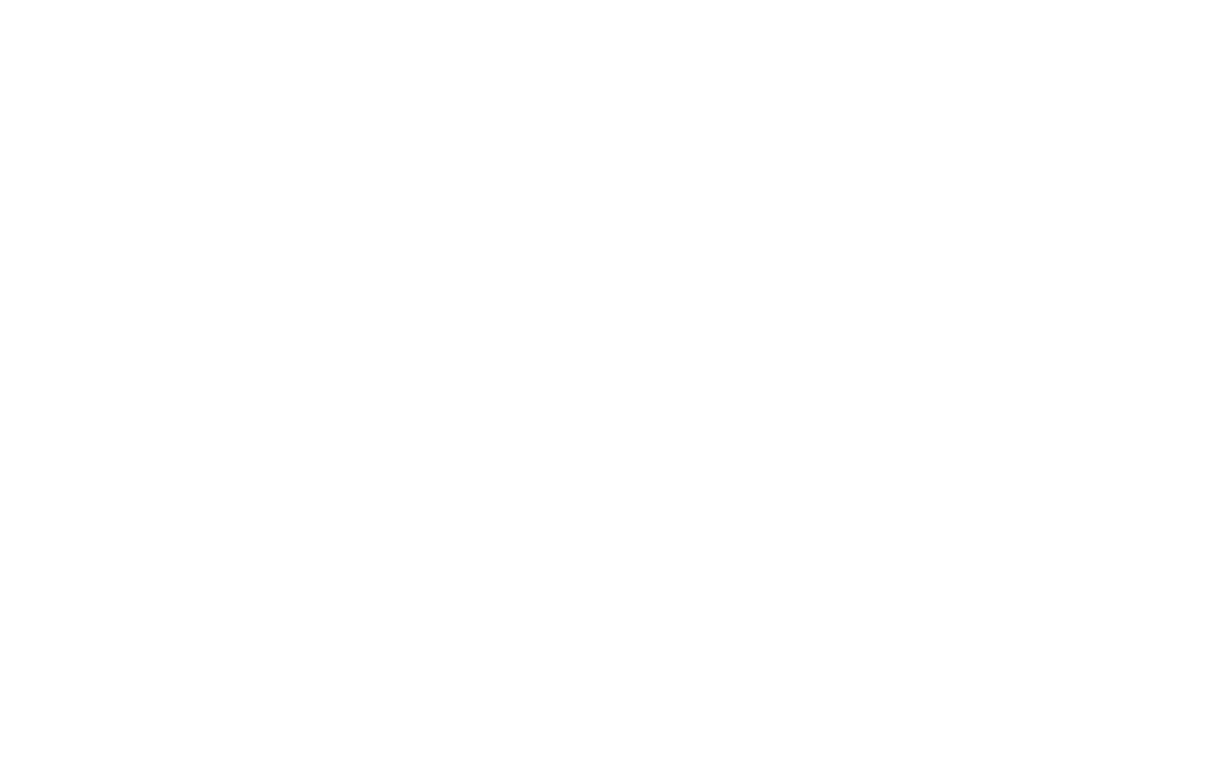

\section{Figure 2. Sensitivity Test: Influences of Employer Parking and Transit Cost Policies and Feeder Bus Frequencies on Probability of Transit-Commuting Among Office Workers}

\section{Midday Travel Behavior}

Surveyed office workers were also asked to report on their midday travel (trips made during the workday which began and ended at the workplace). The predominant mode for midday trips was walking, representing 56.7 percent of all journeys out of and back to the surveyed office buildings during work hours. Trip distance had a strong bearing on midday travel. For trips less than $1 / 4$ mile in distance, 96 percent were by foot. Among midday trips between $1 / 4$ and 1 mile in distance, 73.5 percent were by walking, 22.6 percent were by private automobile, and just 4.7 percent were by transit. Beyond 1 mile, more than 80 percent of trips were by car, and despite the proximity of rail stations, under 5 percent were by transit. Transit's meager share likely reflects the effects of rail's limited geographic coverage in California cities as well as the curtailment of services during nonpeak periods.

Given that more than half of midday trips made by surveyed office workers were by foot, a choice model was estimated for predicting trips by walking instead of mass transit. Because most midday trips occurred within the vicinity of work- 
places, variables related to regional travel times and residential land-use patterns were not considered. A limited set of variables pertaining to travel distance and purpose of midday trips as well as street connectivity near the workplace entered the best-fitting model.

Table 2 presents the logit model that best predicted midday mode choice. All variables in the model were highly significant and the model itself had moderately good predictive powers. The table shows the probability of walking during the midday was higher if the journey was 1 mile or less, consistent with the descriptive statistics previously mentioned. Taking care of job-related business also increased the odds of walking during the midday. Evidently, most out-of-office job-related activities were to nearby destinations, reachable by foot. Lastly, the most relevant policy variable was the level of street connectivity in and around the office site. As the share of intersections within a mile of the office that are four-way or more increases, the odds of walking also rises. Grid street patterns are a hallmark of New Urbanism designs since they provide high levels of connectivity for pedestrians. High connectivity evidently encouraged office workers to walk to midday destinations. The ability to get around in the midday without the need of a car enabled

Table 2. Best-Fitting Binomial Logit Model for Predicting Walk Choice for Midday Trips by Office Workers

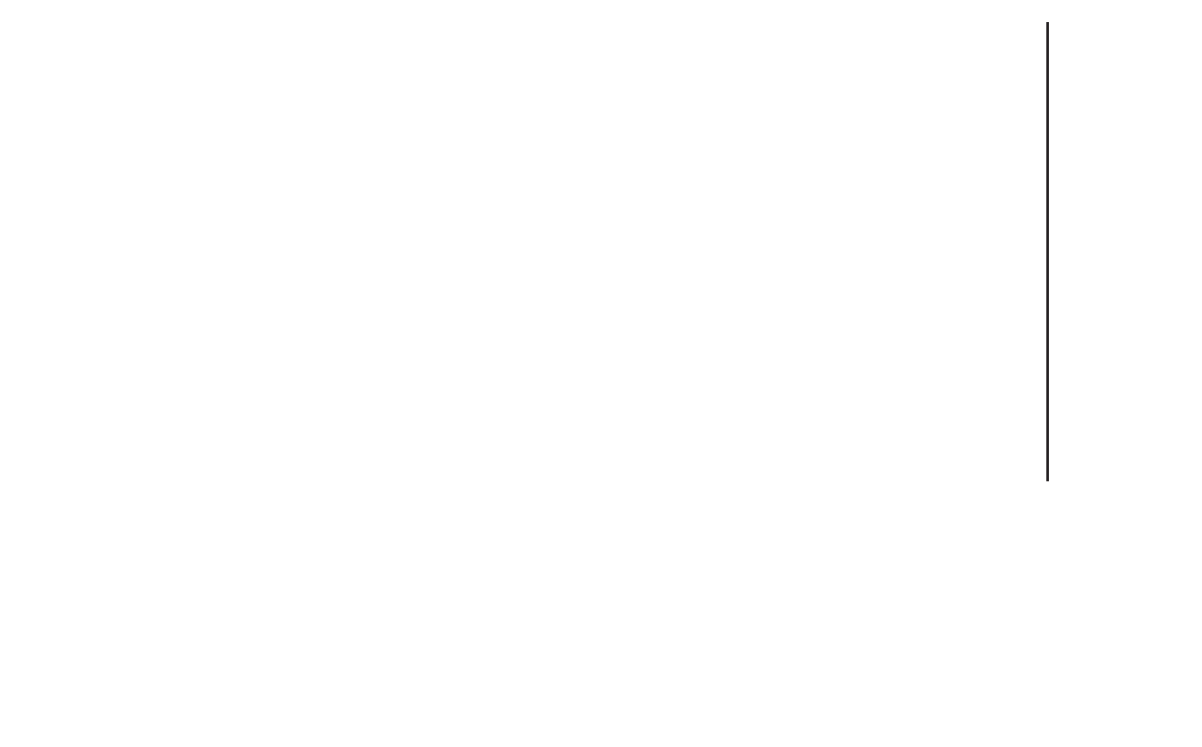


some workers to commute by transit. If they had to drive to reach midday destinations, odds are they would drive to work to have a car on-site.

\section{Conclusions and Policy Responses}

Clearly, a ridership bonus is associated with office development near rail stations in California. This was true in 1992 and even more so in 2003. As congestion levels have worsened over the past decade, more and more office workers are finding it to their liking to take transit to work, notwithstanding the trend toward "edgeless cities" and scattered multitenant office development.

This research found that around one out of five workers in offices outside of large downtowns in California commuted via transit, nearly three times transit's market share of commutes for all workers in the study regions. Workers were most likely to rail-commute if frequent feeder bus services were available at their egress stations, their employer helped cover the cost of taking transit, and parking was in relatively short supply. Factors like the need to chain trips deterred transit riding, however. Over a third of surveyed workers made intermediate stops as part of their commute trips, and over a quarter of the stops were for dropping off or picking up children. Siting child care centers in the vicinity of transit stations-whether at the home- or work-end of the trip-would no doubt promote rail-commuting among many trip-chainers.

Midday travel choices of surveyed office workers were also examined. Most workers walk to midday destinations, such as restaurants and retail shops, if they are reasonably close to their offices; however if destinations are beyond a mile, the vast majority would take a car. Such dependency on a car for midday trips can discourage office workers to commute by transit, even if a rail station lies near their workplace. This underscores the importance of creating mixed-use environments in and around office sites. Islands of stand-alone office buildings, regardless of how close they are to transit, are unlikely to draw many workers to trains and buses if there is a risk of being stranded in the midday, unable to attend to personal affairs (Cervero 1989).

There is likely little need for public policies to encourage office development around rail stations. Many local municipalities have an incentive to zone for office and commercial development near rail stations in the interest of generating higher property tax receipts. In Southern California, for instance, station areas were found to have 340 percent higher shares of commercial zoning than traditional develop- 
ments (Boarnet and Crane 1998). Public policies could help with regard to parking, transit services, and employer incentives. Flexible parking standards that allow below-norm supplies should be considered for all commercial buildings around rail transit stops given the empirical evidence, as shown in this article, that higher shares of worker trips are by transit. Transit's ridership bonus should translate into fewer automobile trips per 1,000 square feet of development and, correspondingly, a reduced need for on-site parking. This research also showed that employer assistance with transit costs matters, even in the case of office buildings close to transit. Beyond the Federal tax credits granted to employers who underwrite the cost of transit-commuting, local governments could consider similar arrangements to further stimulate transit riding. Perhaps public policy-makers can encourage transit-commuting among rail-oriented office workers the most by enhancing both local and regional transit services: the frequency of feeder bus services to stations serving offices as well as comparative travel times by transit were both significant predictors in the models presented in this research.

Policy-makers must not leave it solely to the marketplace to create station-area office environments that are conducive to transit-riding. Regional planning organizations in the San Francisco Bay Area have been very proactive in encouraging transit-oriented housing, such as the Housing Incentive Programs (HIPs) that provide local governments with cash grants (as high as $\$ 2,000$ per bedroom) for housing units built within $1 / 3$ mile of rail stations (Cervero et al. 2004). Policymakers need to be similarly proactive in the case of office development-not so much to encourage transit-oriented offices but rather to encourage site designs, including the arrangements and supplies of parking, and workplace policies, such as employer assistance with transit fares, which promote transit. In the end, concentrating housing near rail stops will do little to lure commuters to trains and buses unless the other end of the trip-the workplace-is similarly convenient to and conducive to using transit.

\section{References}

Bernick, M., and R. Cervero. 1997. Transit villages for the 21st century. New York: McGraw-Hill.

Boarnet, M., and R. Crane.1998. Public finance and transit-oriented planning: new evidence from Southern California. Journal of Planning Education and Research 17 (3): 206-219. 
Cervero, R. 1989. America's suburban centers: The land use-transportation link. Boston: Unwin-Hyman.

Cervero, R. 1994a. Transit-based housing in California: Evidence on ridership impacts. Transport Policy 1 (3): 174-183.

Cervero, R. 1994b. Rail-oriented office development in California: How successful? Transportation Quarterly 48 (1): 33-44.

Cervero, R. 1998. The transit metropolis: A global inquiry. Washington, DC: Island Press.

Cervero, R., and J. Landis. 1992. Suburbanization of jobs and the journey to work: A submarket analysis of commuting in the San Francisco Bay Area. Journal of Advanced Transportation 26: 275-297.

Cervero, R., S. Murphy, C. Ferrell, N. Goguts, and Y. H. Tsai. 2004. Transit-oriented development in the United States: Experiences, challenges, and prospects. Washington, DC: Transportation Research Board, TCRP Report 102.

Dittmar, H., and G. Ohland. 2004. The new transit towns: Best practices in transitoriented development. Washington, DC: Island Press.

Ewing, R. 1998. Transportation and land use innovations. Chicago: APA Press.

Garreau, J. 1991. Edge city: Life on the new frontier. New York: Doubleday.

JHK and Associates. 1987. Development-related survey 1. Washington, DC: Washington Metropolitan Area Transit Authority.

JHK and Associates. 1989. Development-related survey II. Washington, DC: Washington Metropolitan Area Transit Authority.

Lang, R. 2003. Edgeless cities: Exploring the elusive metropolis. Washington, DC: Brookings Institution Press.

Lund, H., R Cervero, and R. Willson, R. 2004. Travel characteristics of transit-oriented development in California. Oakland: Bay Area Rapid Transit District.

Martin, J. 1996. MTS joint development site transit surveys. San Diego: San Diego Association of Governments, unpublished agency report.

McDonald, J., and P. Prather. 1994. Suburban employment centers: The case of Chicago. Urban Studies 31: 201-218. 
RIDES for Bay Area Commuters, Inc. 2004. Commute profiles 2004. San Francisco: RIDES.

\section{About the Author}

Robert Cervero (robertc@berkeley.edu) is professor and chair of the Department of City and Regional Planning at the University of California, Berkeley. His recent research has included studies on the effects of transit-oriented development on travel behavior in California and elsewhere in the United States. 